\title{
MICROBIAL POTENTIOMETRIC SENSOR TECHNOLOGY FOR REAL-TIME DETECTING AND MONITORING OF TOXIC METALS IN AQUATIC MATRICES
}

\author{
Frank C. Brown ${ }^{1}$, Scott R. Burge ${ }^{2}$, Kiril D. Hristovski1 ${ }^{1, *}$, Russell G. Burge ${ }^{2}$, \\ Evan Taylor ${ }^{1,2}$, David A. Hoffman ${ }^{2}$ \\ ${ }^{1}$ The Polytechnic School, Ira A. F ulton Schools of Engineering, Arizona State University, M esa, AZ, USA \\ ${ }^{2}$ Burge Environmental Inc., Tempe, AZ, USA \\ kiril.hristovski@asu.edu
}

\begin{abstract}
Considering that toxic metals can affect metabolic processes in microorganisms adversely, it can be hypothesized that these metals in water matrices would induce a decrease in metabolic activity of the biofilm microorganisms populating the surface of a sensing electrode, which could be registered as a change in the open-circuit potential (OCP) generated by the biofilm microorganisms. The goal of this study was to test this hypothesis and demonstrate the underlying principle that microbial potentiometric sensor (MPS) technology could be used for long-term and real-time monitoring and detection of rapid changes in metal concentrations in realistic aquatic environments. To address the goal, four objective were addressed: (1) a batch reactor with three graphite-based MPS electrodes was fabricated; (2) a set of single-ion solutions and one multiple ion solution were prepared reflecting realistic concentrations of metals found in electroplating wastewaters; (3) the responses of the MPS to the simultaneous presence of multiple toxic metal ions in a single solution were measured; and (4) the changes of the MPS signals to the presence of individual metal ion solutions were examined. While the hypothesis was validated, the study also revealed that the MPS was sufficiently sensitive to not only detect, but also quantify, toxic metal ion concentrations in aqueous solutions. The coefficients of determination, which were $\mathrm{R}^{2}>0.995$, and responsiveness of $<1 \mu \mathrm{mol} / 1$ for some toxic metal cations, strongly support the performance of MPS technology ranking it in the echelons of expensive analytical tools capable detecting and measuring trace elements. The magnitude of the MPS response was toxic metal specific. When the molar concertation normalizes the inhibition portion of the signal area, the assessed sensitivity order was: $\mathrm{Se}>\mathrm{Cd}>\mathrm{Pb}>\mathrm{Ag}>\mathrm{Ni}>\mathrm{Zn}$. The study provides valuable information for enforcement agents, environmental professionals, and wastewater treatment operators, so toxic metal pollution and its detrimental impacts can be prevented and mitigated.
\end{abstract}

Keywords: sensor; microorganisms; potentiometry; toxic metals; galvanization

\section{МИКРОБИОЛОШКА ПОТЕНЦИОМЕТРИСКА СЕНЗОРНА ТЕХНОЛОГИЈА ЗА ДЕТЕКЦИЈА И СЛЕДЕЊЕ НА ТОКСИЧНИ МЕТАЛИ ВО ВОДНИ МАТРИЦИ ВО РЕАЛНО ВРЕМЕ}

Имајќи предвид дека токсичните метали негативно влијаат на метаболичните процеси кај микроорганизмите, може да се постави хипотеза дека овие метали во водни матрици можат да ја намалат метаболичната активност на микроорганизми во биофилмови кои постојат на површината на електроди за детекција. Ова намалување на активноста би можело да се регистрира како промена на напонот генериран од страна на микроорганизмите во биофилмот. Целта на студијата е оваа хипотеза да се тестира и да се покаже принципот дека миробиолошката потенциометриска сензорна (МПС) технологија може да се употреби за долготрајно следење и детекција на наглите промени на концентрацијата на метали во реални водни средини. За да се постигне целта на студијата, беа спроведени четири под-цели: (1) беше конструиран шаржен реактор со три графитни МПС електроди; (2) група едно-јонски раствори и еден повеќе-јонски раствор беа подготвени со реални концентрации на токсични метали кои можат да се најдат во отпадни води од процесите на галванизирање; (3) беше проучувано реагирањето на сензорите на симултаното 
присуство на повеќе токсични метали во еден раствор; и (4) беа испитувани промените на сигналите на МПС во присуство на единечни јони. Покрај тоа што хипотезата беше потврдена, студијата исто откри дека сензорите се доволно осетливи не само да детектираат туку и да ги одредат концентрациите на токсични метали во водни раствори. Коефициентите на детерминација, кои беа $\mathrm{R}^{2}>0,995$, и респонсивноста $<1 \mu \mathrm{mol} / 1$ на некои токсични метални катјони, силно ги поддржаа перформансите на технологијата на МПС, рангирајќи ја во ешалоните на скапи аналитички алатки за детектирање и мерење ниски концентрации на метали. Магнитудата на сигналот на МПС беше специфична за секој токсичен метал. Нормализирањето со моларните концентрации на инхибираторниот дел од сигналната површина го даде редоследот за осетливост: $\mathrm{Se}>\mathrm{Cd}>\mathrm{Pb}>\mathrm{Ag}>\mathrm{Ni}>\mathrm{Zn}$. Студијата овозможува добивање битни информации за инспекциските агенции, профеционалците за животната средина и операторите на прочистителни станици за отпадни води, кои овозможуваат превенција и намалување на загадувањето со токсични метали и нивните негативни последици.

Клучни зборови: сензор; микроорганизми; потенциометрија; токсични метали; галванизација

\section{INTRODUCTION}

Since industrialization began, toxic metal pollution from electroplating operations has been a problem threatening water resources and the ecosystems they support [1]. While the toxicity of the some electroplating metals to living organisms is well established, the demand for electroplated parts and products has led to a marked increase in electroplating operations across the world [2-4]. Most of these operations do not employ wastewater treatment technologies to prevent and mitigate environmental damages from discharges of toxic metals $[5,6]$. Frequently, the toxic metal-laden wastewaters are directly or indirectly released into the hydrosphere or discharged into the sewer systems where they are mixed with municipal sewage or collected stormwaters [7-10]. Because many of these electroplating operations are batch driven processes, most of the toxic metal emissions are characterized by pulse-discharge profiles. This poses significant challenges to operators tasked with monitoring and controlling their wastewater outflows. Most operators rely on monitoring protocols based on intermittent sampling of effluents (e.g., grab samples) followed by laboratory analysis. The approach of periodic sample collection and laboratory analysis does not accurately describe the toxic metal content of water effluents, considering the low sampling frequency and scenarios where irregular intermittent discharges significantly biases the analytical results. Technologies capable of real-time monitoring are needed to identify and document parties illegally discharging regulated toxic metals into the environment. Unfortunately, such technologies that enable continuous, real-time monitoring or detection of toxic metal pollution in natural aquatic or wastewater matrices, are neither cost effective, if available, nor available for most electroplating operations. Without viable monitoring technologies, users are unable to accurately monitor the discharges of pollutants. Regulatory authorities would also greatly benefit from costeffective technologies to enforce regulations and prevent illegal releases of toxic metals into natural or human-made aquatic systems.

The ecotoxicological implications of harmful metals released into natural waters or sewage collection systems are well documented [11-15]. The vast majority of toxic metals interfere with biochemical processes impacting microbial to multicellular organisms [16]. Toxic metal pollutants adversely affect the proper operation of biological wastewater treatment reactors and consequently prevent effective and efficient removal of organic pollutants from the waste-streams and disrupt water reclamation $[8,17]$. Many wastewater treatment operations that receive toxic metal-laden wastewaters are unable to meet their discharge permits because these metals inhibit the metabolism of the microorganisms in the mixed liquor, are present in the effluent discharges, and accumulate in the biosolids, rendering them hazardous waste.

A recent study by Burge et al. [18] demonstrated a novel type of microbial potentiometric sensor (MPS) capable of detecting changes in the local aquatic environment surrounding the biofilm populated sensing electrodes. Considering that toxic metals can affect metabolic processes in microorganisms adversely, it is reasonable to hypothesize that these metals in water matrices would induce a decrease in metabolic activity of the biofilm microorganisms populating the surface of the sensing electrode. This effect could be registered as a change in the open-circuit potential (OCP) generated by the biofilm, as described by Burge et al. (2020). The typical MPS response, the OCP of the biofilm versus $\mathrm{Ag} / \mathrm{AgCl}$ electrode, ranges from 
approximately -700 to $+800 \mathrm{mV}$, depending on the system and the biochemical conditions. The goal of this study is to test this hypothesis and demonstrate the underlying principle that MPS technology could be used for long-term and real-time monitoring and detection of rapid changes in metal concentrations in realistic aquatic environments.

In this study, four objectives were completed to investigate whether the MPS could be utilized to detect the presence and quantify the concentrations of metal ions in solutions. First, a batch reactor with three graphite-based MPS electrodes was fabricated, and the biofilm on the electrodes was cultivated until a steady OCP signal versus the reference electrode was established. Secondly, a set of single-ion solutions and one multiple ion solution were prepared reflecting realistic concentrations of metals found in electroplating wastewaters. Next, the responses of the MPS to the simultaneous presence of multiple toxic metal ions in a single solution were measured. Lastly, the changes of the MPS signals to the presence of individual metal ion solutions were examined.

\section{EXPERIMENTAL APPROACH}

\subsection{Batch reactor fabrication and cultivation of the biofilm on the M PS electrodes}

The cylindrical batch reactor was fabricated from a clear polycarbonate tube with a diameter of $15 \mathrm{~cm}$ and a height of $12.5 \mathrm{~cm}$ (Fig. 1). The total reactor volume was 2.31 . The top of the reactor was equipped with several ports for introduction and removal of solutions. The reactor chamber was equipped with a magnetic stirrer to ensure the complete mixing of solutions within the chamber.

Three graphite MPS indicator electrodes and a commercially-available combination ORP (Model SE300, Milwaukee Instruments) were fabricated into the top and walls of the reactor (Fig. 1). The three MPS and the single ORP were referenced using a single silver/silver chloride electrode fabricated within the combination ORP probe. The MPS electrodes were fabricated from $0.625 \mathrm{~mm}$ graphite rods mounted within a PVC-threaded fitting. The three MPSs, an ORP electrode and the reference $(\mathrm{Ag} / \mathrm{AgCl})$ elecrodes were connected to a high impedance (> $700 \mathrm{M} \Omega$ ) B10 signal acquisition board (Burge Environmental, Inc. Tempe, AZ). The B10 board was connected to a Raspberry Pi computer to transmit the data via a Wi-Fi network to a cloud-based data storage system. An open-source dashboard (Redash) was used to download the data for analysis and visualization.

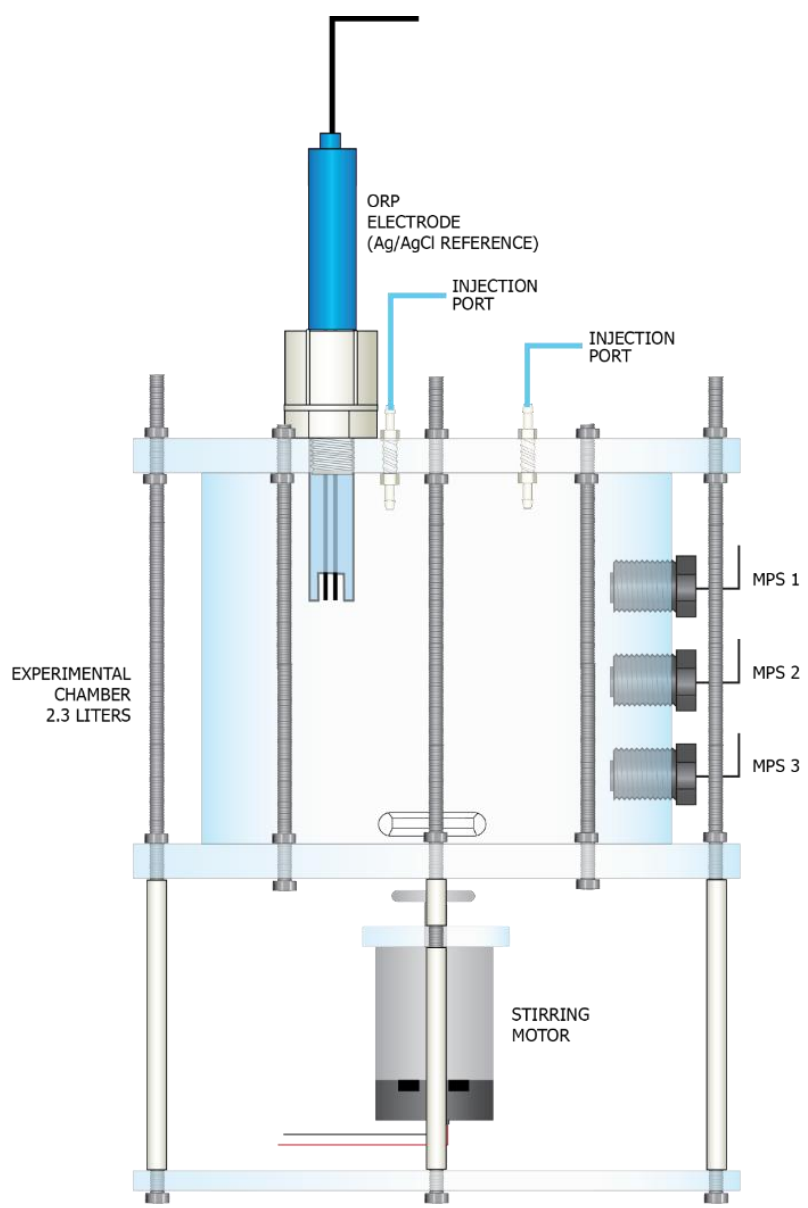

Fig. 1. The batch reactor with all the elements and their position used in this study. The pulse injections into the reactor were performed via the top ports (blue lines), which were kept closed during the experiment to prevent any influences from atmospheric gases.

The reactor was filled with an anaerobic solution generated by mixing dechloronated municipal water with leaf litter (dissolved organic carbon DOC $>80 \mathrm{mg} / \mathrm{l}$; tap water from Tempe, AZ). This anaerobic solution was introduced into the reactor and allowed to equilibrate for a period of more than two months to ensure the population of an endemic biofilm onto the surface of the three MPS graphite electrodes. Two weeks of equilibration typically yield biofilm growth suitable for MPS measurements [18]. During the biofilm cultivation period, the solution was continuously stirred and the experimental chamber was located in a dark room, to prevent the growth of photosynthetic microorganisms, and held at temperature of $23 \pm 1{ }^{\circ} \mathrm{C}$.

\subsection{Preparation of toxic metal solutions representative of industrial pollutants}

Stock solutions were prepared to reflect the toxic metal compositions commonly present in wastewaters entering the international wastewater 
treatment facility at the United States/Mexico border $[19,20]$. The concentration of the final multiple ion solution within the reactor were 4,8 , and 16 times greater than the reported average wastewater metal concentrations, and corresponded to reported peak values. Although somewhat higher than the reported values, these concentrations are an order to two orders of magnitude lower than the toxic metal concentrations released by the metal-plating operations. It is assumed that the actual heavy metal-laden wastewaters at the emission point source are at least 50 to 100 times higher than the concentrations tested in this investigation. For the single ion solution experiments, only concentrations that were four times greater than the average values, as reported at the entrance of the international wastewater treatment plant, were tested. The final toxic metal concentrations introduced into the reactor via a pulse injection are presented in Table 1. The toxic metal cation solutions were prepared using nitrates, acetates, or standard solutions, except for cadmium, where chloride salts were used. Acetate anions were used to provide nutrients for the microorganisms in the biofilm and facilitate the signal recovery. The toxic metal anions used in the study were sodium salts. All salts used in the preparation of the solutions were ACS reagent grade $(>96 \%)$ or higher purity (Sigma Aldrich, Acros Organics, ICN Biomedicals, or Baker). Sodium salt solutions of the counterions (nitrate, acetate, and chloride) were prepared at the same concentrations as the metal solutions and tested to ensure that the changes in the MPS signal resulted from the presence of the toxic metal and not from a matrix effect.

\section{T a ble 1}

\section{Summary of the ion concentrations during pulse injections experiments}

\begin{tabular}{|c|c|c|c|c|}
\hline \multirow{2}{*}{ Element } & \multirow{2}{*}{$\begin{array}{c}\text { Stock } \\
\text { concentration } \\
\mathrm{mg} / \mathrm{l}\end{array}$} & \multicolumn{3}{|c|}{$\begin{array}{l}\text { Final concentration in reactor at injected volume in } \mathrm{mg} / \mathrm{l} \\
\qquad(\mu \mathrm{mol} / \mathrm{l})\end{array}$} \\
\hline & & $10 \mathrm{ml}$ & $20 \mathrm{ml}$ & $40 \mathrm{ml}$ \\
\hline $\mathrm{Cd}$ & 2 & $\begin{array}{l}0.0087 \\
(0.077)\end{array}$ & $\begin{array}{l}0.0174 \\
(0.155)\end{array}$ & $\begin{array}{c}0.03478 \\
(0.309)\end{array}$ \\
\hline $\mathrm{Se}$ & 2 & $\begin{array}{l}0.0087 \\
(0.110)\end{array}$ & $\begin{array}{l}0.0174 \\
(0.220)\end{array}$ & $\begin{array}{c}0.03478 \\
(0.440)\end{array}$ \\
\hline $\mathrm{Pb}$ & 6 & $\begin{array}{l}0.0261 \\
(0.126)\end{array}$ & $\begin{array}{c}0.05217 \\
(0.252)\end{array}$ & $\begin{array}{c}0.10435 \\
(0.504)\end{array}$ \\
\hline As & 5 & $\begin{array}{l}0.0217 \\
(0.290)\end{array}$ & $\begin{array}{c}0.04348 \\
(0.580)\end{array}$ & $\begin{array}{c}0.08696 \\
(1.161)\end{array}$ \\
\hline $\mathrm{Ni}$ & 143 & $\begin{array}{c}0.6217 \\
(10.592)\end{array}$ & $\begin{array}{l}1.24348 \\
(21.184)\end{array}$ & $\begin{array}{l}2.48696 \\
(42.367)\end{array}$ \\
\hline $\mathrm{Ag}$ & 10 & $\begin{array}{l}0.0435 \\
(0.403)\end{array}$ & $\begin{array}{c}0.08696 \\
(0.806)\end{array}$ & $\begin{array}{c}0.17391 \\
(1.612)\end{array}$ \\
\hline $\mathrm{Zn}$ & 230 & $\begin{array}{c}1 \\
(15.259)\end{array}$ & $\begin{array}{c}2 \\
(30.590)\end{array}$ & $\begin{array}{c}4 \\
(61.181)\end{array}$ \\
\hline Total toxic & $\begin{array}{l}\text { concentration } \\
\text { 1) }\end{array}$ & (26.894) & $(53.787)$ & (107.575) \\
\hline
\end{tabular}

\subsection{Examining the microbial potentiometric sensor cumulative response to the simultaneous presence of multiple metals in an aqueous solution}

After the signal of all three active MPS indicator electrodes stabilized, which occurred when the measured microbial response (OCP) was approximately $776 \pm 2 \mathrm{mV}$, multiple ion stock solutions were introduced into the reactor using a syringe (pulse injection volumes of $10 \mathrm{ml}, 20 \mathrm{ml}$, and
$40 \mathrm{ml}$ ). Considering that the hardness of the water was at least $150 \mathrm{mg} / \mathrm{l}$ as $\mathrm{CaCO}_{3}$ and the reactor volume was at least 57 times greater than the injected metal stock solution (i.e., the dilution at 40 $\mathrm{ml}$ injection produced a dilution factor of 57), $\mathrm{pH}$ drifts associated with the injections were considered negligible and did not meaningfully influence the experiment.

The response data was evaluated by integrating the area of the curve between the highest and lowest point of the generated signal, which corre- 
sponds to the inhibition portion of the signal. This data analysis method ensured that only the inhibiting effects of the toxic metals on the metabolic activities of the microorganisms were reported as results. The reasoning behind this type of signal area integration was based on the behavior of the microorganisms in the biofilm upon exposure to toxic chemicals. When toxins are introduced, the MPS signal rapidly decreases and correlates to the inhibition of the metabolic (e.g., electron generation/cytochrome storage) processes [18]. Once toxic metals are immobilized, or otherwise removed from the environment, the inhibitory effects are eliminated, and normal metabolic activities resume, which can be observed by a characteristic increase in the microbial OCP signal (recovery portion of the signal).

\subsection{Examining the microbial potentiometric sensor response to aqueous solutions with a single toxicmetal ion}

Six of the seven toxic metals investigated in the cumulative response were used to examine the MPS response to individual metal ions. Specifically, MPS responses to $\mathrm{Se}, \mathrm{Cd}, \mathrm{Pb}, \mathrm{Ag}, \mathrm{Ni}$, and $\mathrm{Zn}$ were investigated. For each toxic metal investigated, separate aliquots of $10 \mathrm{ml}$ of each single-ion solution were pulse injected into the reactor. For silver, aliquots of $10 \mathrm{ml}$ and $20 \mathrm{ml}$ were injected to confirm the observation from the multiple ion solution tests and to observe if the same pattern exists for single ions where doubling the concentration for a single ion results in an increase in signal magnitude. Because the objective was to see whether there will be a response, and not to quantify and calibrate the response, the injections were conducted once the signal reached $\pm 5 \mathrm{mV}$ of the stable baseline. This approach demonstrated that the sensors could respond even when the biofilm has not fully recovered from the preceding toxic metal inhibition. This test indicates that MPS is suitable for industrial applications that require realtime data because the sensor does not need to fully recover the baseline microbial response to generate meaningful results before the sensor is exposed to additional toxins. The integrated area of the inhibition portion of the signal was divided by the concentration to compare the relative MPS response to each toxic metal. Although not as accurate as creating a calibration curve for each element, this type of signal normalization allows for approximate evaluation of the relative impact of each toxic metal on the MPS signal.

\section{RESULTS AND DISCUSSION}

\subsection{Microbial potentiometric sensor responses to aqueous solutions with toxic metal mixtures}

Figure 2a illustrates the responses of the three MPSs to the simultaneous introduction of different concentrations of mixed toxic metals. The area of the valleys (inverse signal peaks) increased with doubling and quadrupling the concentrations of the metals within the reactor. When the net molar concentrations, comprised of the concentration of all ions, were plotted against the integrated areas of the inhibition portion of the signal, three-point calibration curves were obtained for each of the MPS electrodes. As illustrated in Figure $2 b$, the $R^{2}$ values for all three curves, representing each MPS electrode, exceeded 0.995 . These highly correlative relationships between the concentrations of metal ions and integrated areas of the microbial responses exceeded the expectation beyond the postulated hypothesis that the sensors will respond to the presence of toxic metals in water, and strongly suggested the utility of the MPS to quantify metal concentrations in industrial settings. Such high coefficients of determination exceed the performance of many analytical methods which are currently accepted as standards in water quality analysis [21, 22]. The MPS 3 electrode appeared to be the most sensitive to the induced changes, as illustrated by the highest slope of the calibration curve. Sensitivity differences among MPS electrodes are expected because of the composition and nature of biofilm on the individual graphite surfaces may vary. Considering that the biofilm sensing surface is a living organism populating the graphite surface of the MPS, no two biofilms on the individual MPSs are expected to be exact duplicates. The biofilms may vary based on microbial composition, density, thickness of the biofilm and several other factors. While the MPSs may not exhibit identical signal response in terms of the magnitude of the signal response (and subsequent recovery) to a toxic metal, each MPS is capable of responding to stimuli in the same manner (e.g., toxins will inhibit metabolic processes followed by a gradual recovery of the metabolic processes). As such, even when placed in the same environment, two biofilms may not recover identically from an adverse effect of a same toxin. 
(a)

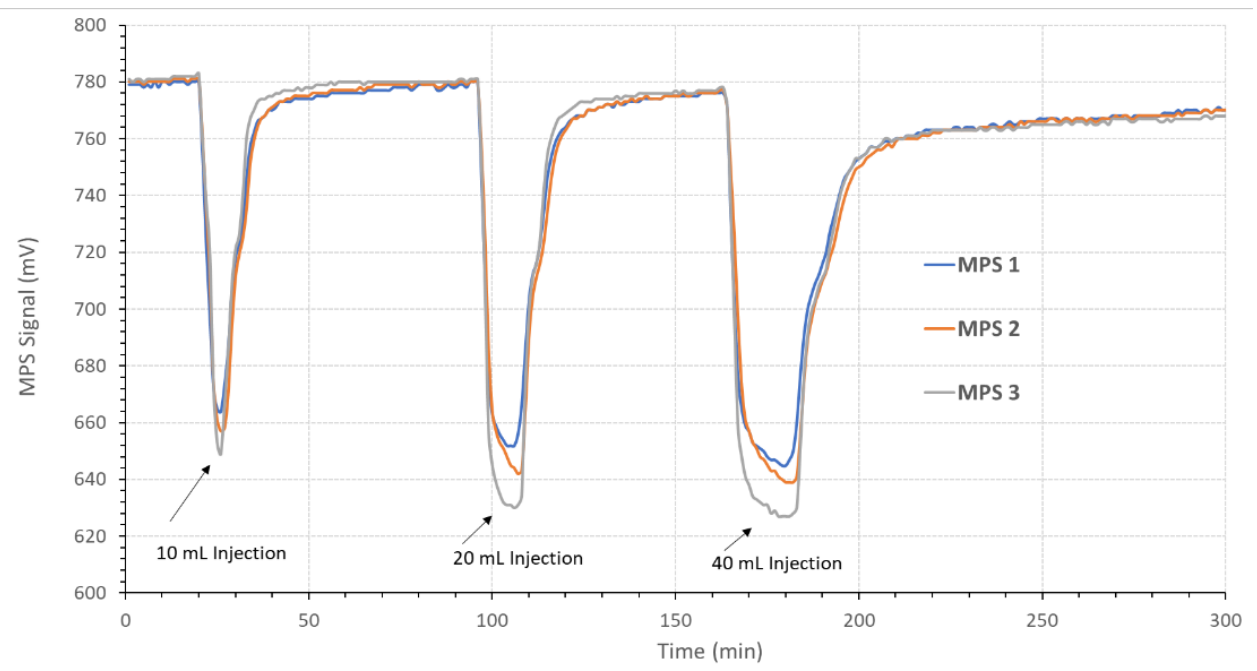

(b)

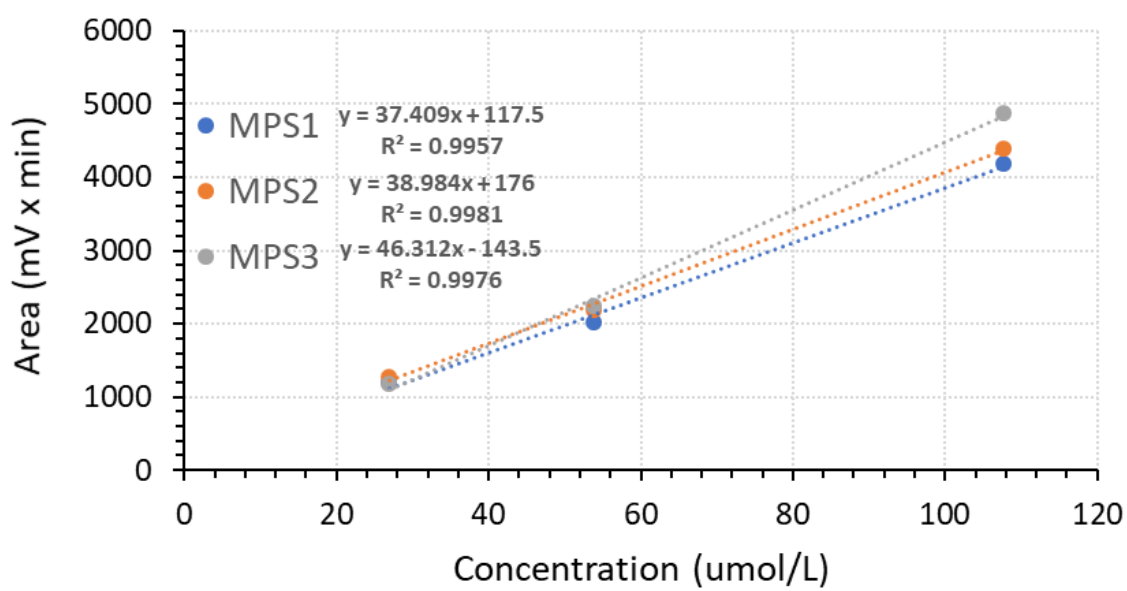

Fig. 2. (a) Responses of all three active microbial potentiometric sensors (MPS) to the simultaneous introduction of different concentrations of mixed toxic metals; (b) Three-point calibration curves for the multiple toxic metal solution show an increase in signal with doubling and quadrupling the multiple ion concentrations and the corresponding coefficients of determination $\left(\mathrm{R}^{2}\right)$.

Table 1 summarizes the actual total net concentrations for the different pulse injections. The MPS were able to detect toxic metal concentrations down to $\sim 27 \mu \mathrm{mol} / 1$ (10 $\mathrm{ml}$ injections). The shape and magnitude of the signals suggest that this sensor technology can detect even lower concentrations of metals in water matrices. Furthermore, the form of the signal indicated that the biofilm is capable of recovering to its baseline conditions relatively quickly, which is likely due to the ability of microorganisms to immobilize the toxic metals and neutralize its toxic effects. When the control solution was added (no toxic metals), the signal decreased about 3 to $4 \mathrm{mV}$ for a few minutes, which was a couple of $\mathrm{mV}$ over the baseline signal variation. These results suggest that the sensitivity of the MPS technology may be even higher, however, it would be challenging to differentiate a $4 \mathrm{mV}$ signal change to a $\pm 2 \mathrm{mV}$ baseline signal (noise). Because this is a first study of this kind, there is no literature available. Consequently, it is impossible to compare the heavy metal sensitivity of this technology with other data.

\subsection{Microbial potentiometric sensor response} to the presence of a single individual toxic metal concentrations in an aqueous solution

Figure 3 illustrates the responses of the MPS electrodes to individual toxic metal ions. Although the magnitude of the response varied slightly, the shape of the response curves for each electrode was similar for an individual toxic metal. The magnitude of the two Ag response curves for different concentrations was consistent with the trends observed for the injections of aqueous solu- 
tions containing mixtures of toxic metal ions. All MPS electrodes produced higher signals as the silver concentration increased.

The nickel injection indicated the MPS 3 signal did not fully recover to its original baseline value, this observation is probably due to the significant toxic effect created by the high nickel concentration. Nonetheless, this baseline did not affect the performance or sensitivity of the MPS 3 electrode for the inhibition portion of the signal, which was evident in the response curves of the metals following the nickel injection. It could be postulated that MPS 3 would have returned to a normal baseline if sufficient recovery time was allowed; however, this aspect of the experiment was beyond the exploration scope of this study.
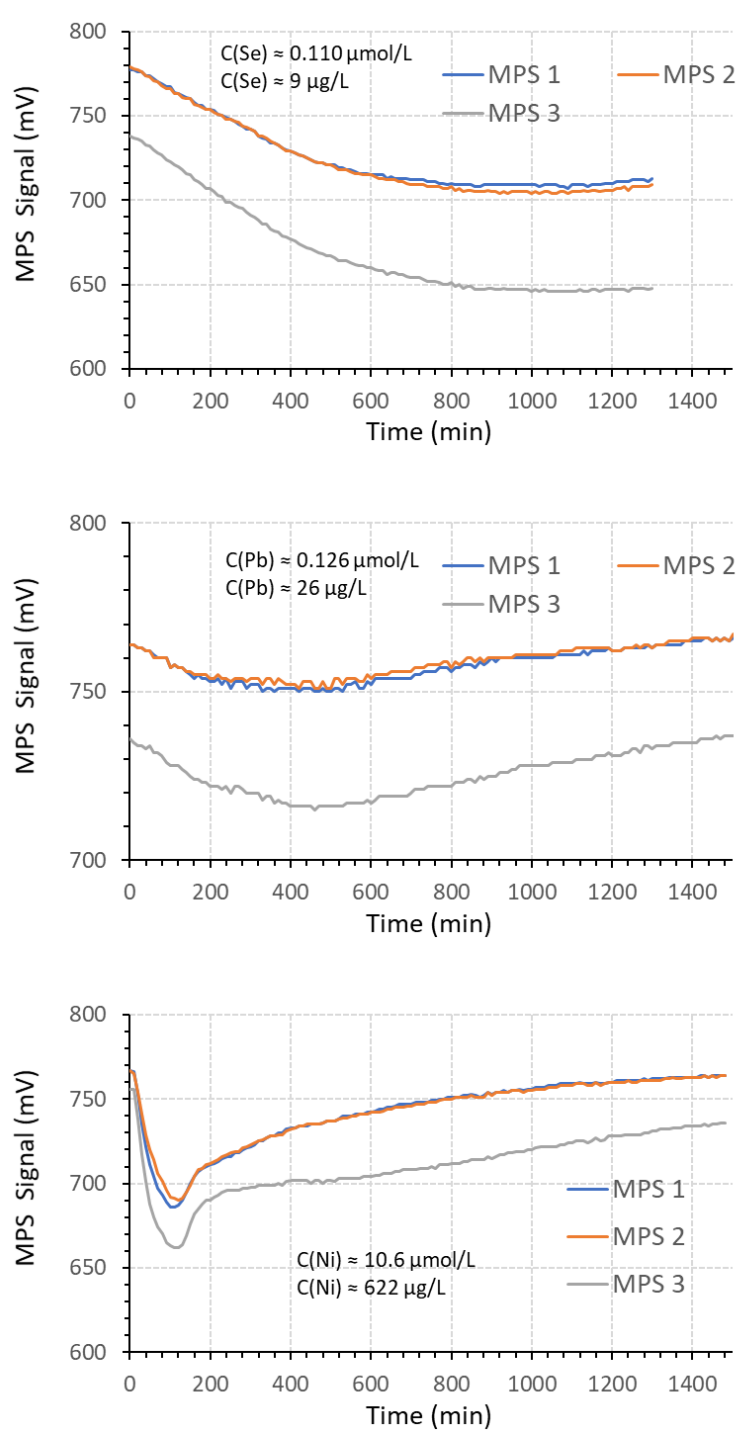

From Figure 3, it can be observed that the MPS exhibited highest sensitivity to selenium and lowest sensitivity to zinc. When the molar concentration normalizes the inhibition portion of the signal area, the following sensitivity order could be proposed: $\mathrm{Se}>\mathrm{Cd}>\mathrm{Pb}>\mathrm{Ag}>\mathrm{Ni}>\mathrm{Zn}$. Although this sensitivity order must be confirmed by comparing the responses for the same molar concentrations, the sole fact that the sensors could differentiate toxic metals is beyond the expectations of this study. Furthermore, the ability of this technology to detect concentrations of $<1 \mu \mathrm{mol} / 1$ (i.e., $<10$ $\mu \mathrm{g} / \mathrm{l})$ for some toxic metals surpasses any assumptions inferred in the hypothesis of this study.
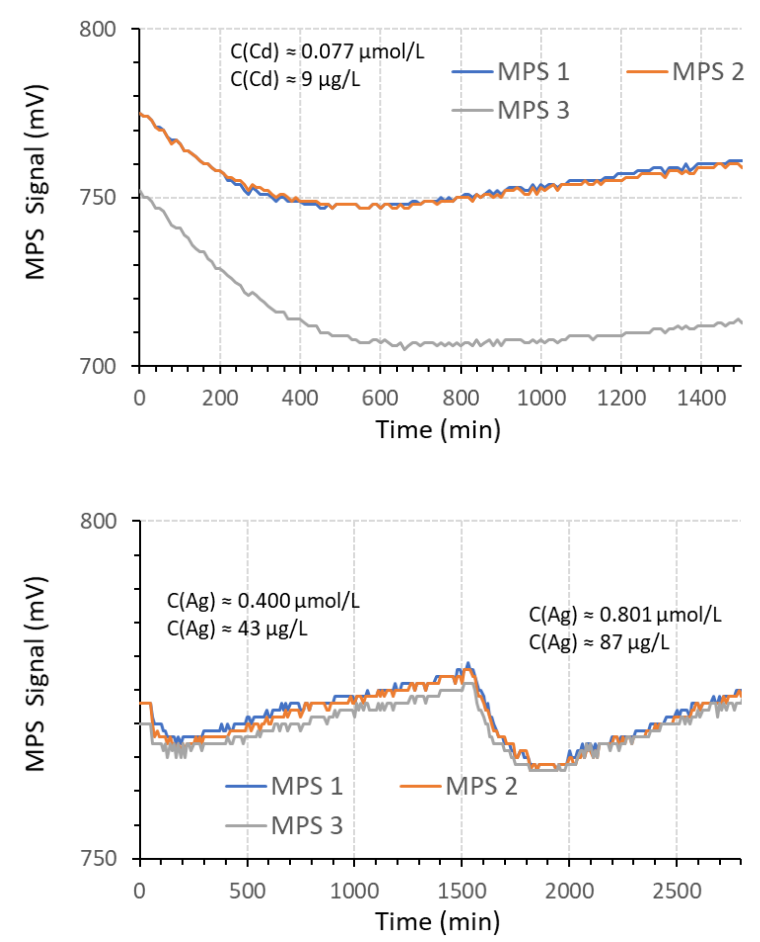

Fig. 3. Responses of the MPS electrodes to $10 \mathrm{ml}$ pulse injection of individual toxic metal ions.

Two pulse injections of $10 \mathrm{ml}$ and $20 \mathrm{ml}$ for $\mathrm{Ag}$ were performed. 


\section{CONCLUSIONS}

The goal of this study was to demonstrate the underlying principle that MPS technology could be used for real-time monitoring and detecting rapid changes in toxic metal concentration in aquatic environments. This study represents a first of its kind and opens new avenues for developing heavy metal monitoring strategies.

During the investigation, the original hypothesis was validated, however, the study also revealed other unique capabilities of this sensor technology. The experiments indicated that the MPS was sufficiently sensitive to not only detect, but also quantify, toxic metal ion concentrations in aqueous solutions. The coefficients of determination, which were $\mathrm{R}^{2}>0.995$, and responsiveness of $<1 \mu \mathrm{mol} / 1$ for some toxic metal cations, strongly support the performance of MPS technology, ranking it in the echelons of expensive analytical tools capable detecting and measuring trace elements. The drawback, however, of traditional analytical tools compared to the MPS is that they are significantly more expensive, cost more to manage, and cannot be operated in a continuous, real-time, and long-term monitoring mode. Following the maxim, "if it cannot be monitored, it cannot be enforced", the MPS technology enables real-time monitoring of toxic metal pollution in aquatic environments. Results from MPS provide valuable information for enforcement agents, environmental professionals, and wastewater treatment operators, so toxic metal pollution and its detrimental impacts can be prevented and mitigated. The low cost of MPS technology could significantly reduce the expenses associated with environmental remediation and treatment if an environment is contaminated. When coupled with artificial intelligence technology and other data, MPS technology may offer a unique opportunity to become the tool for complete monitoring of toxic pollution in aquatic environments.

In context of understanding the mechanistic details driving the performance of this technology, further research would need to be conducted. Elucidating how specific toxic metals affect the changes in the open-circuit potential could advance the understanding of this technology and help optimize its sensitivity. However, these research questions are beyond the scope of this study and represent a foundation for future quests.

Acknowledgements. This material is based upon work supported the US Department of Energy, Office of Science, Office of Biological and Environmental Research under Grant No. DE-SC0013194 SBIR Project "Automated Monitoring of Subsurface Microbial Methabolism with Graphite Electrodes"
Special gratitude to Ms. Michell Peppers for her help with the illustrations and administrative support. Gratitude to Mr. Evan Taylor for providing support with the software and hardware.

\section{REFERENCES}

[1] S. Wang, X. Xu, Y. Sun, J. Liu, H. Li, Heavy Metal Pollution in Coastal Areas of South China: A Review. Marine Pollut. Bull., 76 (12), 7-15 (2013). DOI: 10.1016/j.marpolbul.2013.08.025.

[2] B. Daylan, N. Ciliza, A. Mammodov, Hazardous Process Chemical and Water Consumption Reduction through Cleaner Production Application for a Zinc Electroplating Industry in Istanbul.” Res. Conser. Recyc., 81, 1-7 (2013). DOI: 10.1016/j.resconrec.2013.09.002.

[3] H. H. Vardhan, P. S. Kumar, R. C. Panda, A Review on Heavy Metal Pollution, Toxicity and Remedial Measures: Current Trends and Future Perspectives. J . M olec. Liq., 290, 111197 (2019). DOI: 10.1016/j.molliq.2019.111197.

[4] A. Gorokhovsky, M. Vikulova, J. I. Escalante-Garcia, E. Tretyachenko, I. Burmistrov, D. Kuznetsov, D. Yuri, Utilization of Nickel-Electroplating Wastewaters in Manufacturing of Photocatalysts for Water Purification. Process Saf. Environ. Protect., 134, 208-216 (2020). DOI: 10.1016/j.psep.2019.11.040.

[5] Y. Geng, M. Wang, J. Sarkis, B. Xue, L. Zhang, T. Fujita, Spatial-Temporal Patterns and Driving Factors for Industrial Wastewater Emission in China. J. Clean. Prod., 76, 116-124, (2014). DOI: 10.1016/j.jclepro.2014.04.047.

[6] N. K. Pareek, Industrial Wastewater Management in Developing Countries, Water Sci. Technol., 25 (1), 6974 (1992). DOI:10.2166/wst.1992.0011.

[7] M. Kumar, H. Furumai, I. Kasuga, F. Kurisu, Metal Partitioning and Leaching Vulnerability in Soil, Soakaway Sediments, and Road Dust in the Urban Area of Japan. Chemosphere, 252, 126605 (2020). DOI: $10.1016 /$ j.chemosphere.2020.126605.

[8] M. Kumar, A. Gogoi, S. Mukherjee, Metal Removal, Partitioning and Phase Distributions in the Wastewater and Sludge: Performance Evaluation of Conventional, Upflow Anaerobic Sludge Blanket and Downflow Hanging Sponge Treatment Systems. J. Clean. Product., 249, 119426 (2020). DOI: 10.1016/j.jclepro.2019.119426.

[9] C. Zhou, S. Ge, H. Yu, T. Zhang, H. Cheng, Q. Sun, R. Xiao, Environmental Risk Assessment of Pyrometallurgical Residues Derived from Electroplating and Pickling Sludges, J . Clean. Produc., 177, 699-707 (2018). DOI: 10.1016/j.jclepro.2017.12.285.

[10] Q. Zhou, N. Yang, Y. Li, B. Ren, X. Ding, H. Bian, X. Yao, Total Concentrations and Sources of Heavy Metal Pollution in Global River and Lake Water Bodies from 1972 to 2017, G lobal E col. Conserv., 22, e00925 (2020). DOI: 10.1016/j.gecco.2020.e00925.

[11] P. Amundsen, F. J. Staldvik, A. A. Lukin, N. A. Kashulin, O. A. Popova, Y. S. Reshetnikov, Heavy Metal Contamination in Freshwater Fish from the Border Region between Norway and Russia, Sci. Tot. Environ, 201 (3), 211-244 (1997). DOI: 10.1016/s0048-9697(97)84058-2. 
[12] S. Ma, H. Zhang, S. Ma, R. Wang, G. Wang, Y. Shao, C. Li, Effects of Mine Wastewater Irrigation on Activities of Soil Enzymes and Physiological Properties, Heavy Metal Uptake and Grain Yield in Winter Wheat, E cotox. Environ. Saf., 113, 483-490 (2015). DOI: 10.1016/j.ecoenv.2014.12.031.

[13] S. Costa-Böddeker, L. X. Thuyên, P. Hoelzmann, H. C. de Stigter, P. van Gaever, H. Đức Huy, J. P. Smol, A. Schwal, Heavy Metal Pollution in a Reforested Mangrove Ecosystem (Can Gio Biosphere Reserve, Southern Vietnam): Effects of Natural and Anthropogenic Stressors over a Thirty-Year History, Sci. Tot. Environ., 716, 137035 (2020). DOI: 10.1016/j.scitotenv.2020.137035.

[14] B. T. Nguyen, D. D. Do, T. X. Nguyen, V. N. Nguyen, D. T. P. Nguyen, M. H. Nguyen, H. T. T. Truong, H. P. Dong, A. H. Le, Q. Bach, Seasonal, Spatial Variation, and Pollution Sources of Heavy Metals in the Sediment of the Saigon River, Vietnam, Environ. Pollut, 256, 113412 (2020). DOI: 10.1016/j.envpol.2019.113412.

[15] J. A. Vilas-Boas, S. J. Cardoso, M. V. X. Senra, A. Rico, R. J. P. Dias, Ciliates as Model Organisms for the Ecotoxicological Risk Assessment of Heavy Metals: A Meta-Analysis. Ecotoxicol. Environ. Saf., 199, 110669 (2020). DOI: 10.1016/j.ecoenv.2020.110669.

[16] X. Zeng, S. Li, Y. Leng, X. Kang. Structural and Functional Responses of Bacterial and Fungal Communities to Multiple Heavy Metal Exposure in Arid Loess. Sci. Tot. Environ., 723, 138081 (2020). DOI: $10.1016 /$ j.scitotenv.2020.138081.
[17] S. A. Bhat, G. Cui, W. Li, Y. Wei, F. Li, Effect of Heavy. Metals on the Performance and Bacterial Profiles of Activated Sludge in a Semi-Continuous Reactor, Chemosphere, 241, 125035 (2020).

DOI: $10.1016 /$ j.chemosphere.2019.125035.

[18] S. R. Burge, K. D. Hristovski, R. G. Burge, D. A. Hoffman, D. Saboe, P. Chao., E. Taylor, S. S. Koenigsberg, Microbial Potentiometric Sensor: A New Approach To Longstanding Challenges, Sci. Tot. Environ. 742, 140528 (2020). DOI: doi.org/10.1016/j.scitotenv.2020.140528

[19] H. Huth, Nogales International Wastewater Treatment Plant, AZPDES-Permit Modifications to Improve Communication and Binational Support, IBWC Binational Technical Committee Meeting, Nogales AZ, USA. February 12, 2014.

[20] M. B. Lester, C. van Riper III, Distribution and Extent Of Heavy Metal Accumulation In Song Sparrows (Melospiza Melodia), Upper Santa Cruz River Watershed, Southern Arizona, 2011-12: U.S. Geological Survey O pen--F ile Report, 2014-1072, 2014. DOI: dx.doi.org/10.3133/ofr20141072.

[21] U.S. Geological Survey, Guidelines and Standard Procedures for Continuous Water-Quality Monitors: Site Selection, Field Operation, Calibration, Record Computation, and Reporting. Reston: U.S. Geological Survey, 2000 .

[22] APHA. Standard methods for the examination of water and wastewater, 23sted. Washington, DC, New York, American Public Health Association (2018). 
